\title{
SPEECH GIVEN ON THE 12th OF OCTOBER 2017 ON THE OCCASION OF BEING AWARDED THE DOCTOR HONORIS CAUSA TITLE OF THE BABEŞ-BOLYAI UNIVERSITY CLUJ-NAPOCA ${ }^{1}$
}

\section{KATHERINE VERDERY²}

Esteemed Pro-rector Rus, Dean Hărăguș, Professors Raț and Culic, honored guests,

Thank you for your most-beautiful words and for this wonderful occasion. It is an unequalled honour, for which I am deeply grateful - especially to my fellow sociologists. Even though I call myself not a sociologist but a "social-cultural anthropologist," my relationship with Sociology is a long and cordial one. It began at university when I took the course "Introduction to Anthropology," only to learn that much of the material had been written by sociologists. For the rest of my career I have maintained a certain confusion about the division of labour between these two fields of investigation of human life. Today you confirm their resemblance, acknowledging the kinship relation between them. In a word, you have adopted me, and it's good: I feel at home.

If you do me this great honour, I should thank you in your own language. I apologize for the unavoidable mistakes and for the fact that this speech is given in a simpler language - a language that was learned not primarily from books, but in a village, talking with people.

Because my audience today is mixed, I thought that rather than presenting a summary of my work in Romania, I would offer something more personal, about this work's "infrastructure" in my relations here. Instead of giving a new interpretation of some material, I would like to present a brief homage to a few people in Romania who supported the career that I built here and without whom I couldn't have advanced much in my projects. Because the list is very long, I will mention only a few names. You will see that my talk also concerns the methods of ethnography.

\footnotetext{
${ }^{1}$ Translated from Romanian by Irina Culic and revised by Katherine Verdery.

2 Distinguished Professor of Anthropology, Graduate Center of the City University of New York, e-mail: kverdery@gc.cuny.edu.
} 
I start with Professor Mihai Pop, who was the head of the Institute of Ethnography and Folklore when I arrived in 1973. Without him I wouldn't have gotten to Romania at all. For my first research, I had applied for an academic exchange fellowship (IREX), but the Romanian authorities rejected me. Since American-style anthropology did not have a disciplinary partner in Romania, my project fell between two stools: too sociological for folklorists, and too folkloristic for sociologists. But IREX's president, Allen Kassof, called Professor Pop directly and asked him, as a personal favour, to take me under his wing. The professor accepted and, throughout that year, when I visited Bucharest he would tell me about village life in Romania, in particular as seen from his birthplace, Maramureș. He suggested that I should settle in Hunedoara County for my project, and, after I unintentionally drove my Mobra moped right into a military base there, the professor took the train from Bucharest to Deva, an eight-to-ten-hour trip at the time, to talk to the "chiefs" there and find an acceptable place for me in another part of the county. After that, I called him "nănaşu"' (godfather).

I don't know if Professor Pop realized from the beginning that, although I was a nice girl, I knew very little about ethnography. I was far too caught up in sociological macro-theories and had no fieldwork training. My doctoral program in Anthropology at Stanford, like everywhere else in the United States at the time, did not offer fieldwork methods. Either his intuition or just his everyday professionalism led Professor Pop to do something for me that was absolutely extraordinary. After we had arrived together in Aurel Vlaicu, the site of my research, and he had persuaded an unfortunate couple to provide me lodging, he asked the wife to give a small party towards the evening and to invite her parents, some neighbours, and the director of the village school. When they had poured the wine and served the cakes, the professor started interviewing those present, offering me a splendid example of precisely what I lacked. He talked about village history, marriage and kinship, internal migration, and many other topics. He kept an alert, but also relaxed, friendly pace. I noted his unfailing smile, his courtesy, the way he addressed questions in a down-to-earth way of speaking, reducing the social distance between them. It was the best possible lesson for a novice fieldworker.

Regrettably, his lesson was not fully learned.

A skilled ethnographer must keep her ears open all the time, to understand what the world looks like from the viewpoint of her interlocutor. By contrast, I tended to listen only up to a certain point and then start expressing my own ideas, which kept me from discovering theirs. Let me give you an example. One day I stopped at one of the women I had made friends with, Veca. I caught her in a bad moment, as she was lying in bed on her stomach and her sister-in-law was applying suction cups to her back. The sister-in-law held a small glass in 
her hand; with the other she used a candle to light a little stick wrapped in cotton and soaked with alcohol; she put the burning stick into the glass, and immediately after, the glass on Veca's back. The little glasses stuck there and bruises began to develop under them. What the hell!?, I thought. I asked them why they were doing that, and they explained that Veca had caught a cold and the suction cups would pull the cold out of her - as already seen in the bruises. I looked at them stupefied and started to talk about aspirin, cough syrup, maybe antibiotics, and so on. I didn't try to explore their ideas, these practices of popular medicine: I told them they shouldn't do it. To this day I am still ashamed of myself.

Professor Pop was not the only one to try to teach me research methodology; so had his colleague, the Romanian sociologist I most admire: Henri H. Stahl. Professor Pop introduced me to him in 1973, and I started visiting him every time I travelled to Bucharest from Vlaicu. In our first discussion, he advised me how to work with the villagers in the field. Among other things, I should bring some forms of witchcraft, to trade for theirs. He explained to me how he himself had learnt this lesson. It seems that around the time of his research in the 1930s, he took his typewriter to the village, a thing of wonder for everyone there. Increasingly fascinated, more and more people came to ask for him to type all sort of things. Late one night, the village witch came to his place, seemingly displeased by this competition in the Dark Arts. "All right," she said. "Tell me what I have to do to make you leave." Through examples like this one, Professor Stahl wanted to warn me that the ethnographer always has to be alert and far-sighted, that the villagers are not "simple people" at all, as town dwellers believe.

Maybe my self-criticism is too harsh, but I feel that at the beginning I did not know how to do ethnography, despite the example of these two master fieldworkers, to whom I now offer praise. To support this self-critical opinion, I cite from my Securitate file a part of a telephone call between two colleagues, "F" and "N," from Cluj.

F: - I have the impression that the ethnography she does picks and chooses from a number of domains without going into depth in the European style. I don't know if this is good or bad but I've seen like with her discussion of Philosophy, three words from here, four from there... $\mathrm{N}$ : - Pretty much. Probably it's an excellent instrument for informing the public over there, because she synthesizes things admirably, you know... It's just that it's as if taken from an airplane. 
If after my first research I nonetheless succeeded in writing a book that was well received, I believe I owe that to professors Pop and Stahl and to my endless discussions not with the villagers, but with them.

Another person to whom I wish to give homage is Maria, my first hostess in Vlaicu. She was a warm, generous presence, with a somehow saintly air, for which reason I baptized her "Meri" (Mary), the English name of Jesus's mother. After Professor Pop's departure for Bucharest, I remained alone with Meri. We started talking and quickly became friends. She immediately convinced me that, although she had finished only seventh grade, she had a sharp mind and unusual powers of observation and synthesis - ideal for a beginning ethnographer. We still love each other now, forty-four years later, when she is age ninety-one.

Meri was my most valuable interlocutor in Vlaicu. I spent countless hours with her, talking about everyone in the village: where every villager was from, their nicknames, their godparents, where they worked, what people said about them, etc. She sent me to various families who became essential interlocutors and integrated me into her circle of friends. I also became and remained good friends with her son and his family, who still live in Vlaicu, and with her daughter in Bucharest.

In an interview for a documentary, Meri explained something I had not realized before.

I liked her right from the moment I met her. My daughter had just gotten married and moved to Bucharest, and my heart was aching because she went away. And so, when Kati came, I told myself it was good to have someone around here, with me.

Translating our relation into the language of kinship, she has often told me that she loves me like her own daughter. And I her, like a mother. Such a relationship generates a context for gaining knowledge that is completely different than in other social sciences.

I became close to many Vlăiceni, but for this first year of research I mention only three, to whom Meri sent me: the families of uncle Petru Bota, aunt Lina Iancu, and Phillip Schmidt. The first two of them had completed fourth grade and were born in Vlaicu in 1891 and 1894, he to a family of day-labourers, she to a rich peasant family; they were already old when I met them and had a lot of time at their disposal. Both had keen minds and were full of good will. Aunt Lina shared many memories about the relations between Romanians and Hungarians, and uncle Petru, to whom I dedicated my first book, taught me a lot about the village economy in the past. The third person, Phillip Schmidt (the population of Vlaicu comprised 20 percent Germans), a warehouseman in a factory who 
had graduated from a trade school, was a treasure of information about the nineteenth-century Swabian colonization of the village. The evenings spent with his family truly felt like a seminar (only with better food).

These are several of the people without whom my first research and the resulting book would not have been possible. For the second book, National Ideology Under Socialism (translated into Romanian as Compromis și rezistență), the most influential character was Professor David Prodan. I met him in November 1979, during a short visit to the state archives in Budapest, where the director of the Transylvanian archive introduced me to him. I saw before me a little old man wearing a navy blue beret over rich grey hair. His eyes sparkled with ferocious intelligence through his big glasses. I fell for him instantly. During the conversation he offered to help me access the state archives in Cluj, which he later did, persuading a reluctant director to accept me and provide me with a translator for the documents in the Hungarian language, which I don't know. Not only did he introduce me to the world of the Hungarian aristocracy in Transylvania, a world that came to fascinate me; he also introduced me to the library of the Academy, where I began a long and productive reading of the history of Transylvania and made friendships that would last until today (two of these friends are present here).

More important in the help that he gave me, however, was his explosive reaction to a mistake I had made in the book based on these readings: two jokes using ethnic stereotypes about Romanians, Germans, and Hungarians, intended to state the theme of the book (changes in interethnic relations in Transylvania across three social systems: feudalism, capitalism, and socialism). At home, for their intended audience the jokes opened a window onto a place about which Americans knew nothing. But - in a classic problem of transcultural translation here the jokes were seen as an insult. The professor (alongside many other Romanians) got terribly angry. From his reaction I quickly understood that the jokes had been a stupid idea and I was full of remorse. I would have much better used the joke that he himself had told me: Transylvania, 1896. A Hungarian and a Romanian are chatting. The Hungarian, boasting about the thousand-year anniversary of Hungarian presence in Transylvania, asks the Romanian, "So, what about you? When are you going to celebrate your millennium?" And the Romanian answers, "Well, no need, since we're from here."

I suffered his anger for four months. Eventually we made up, but meanwhile I had learnt that I had no clue about the power of the national idea, so deeply rooted in the souls of all Romanians. As a result, in my next project, I decided to explore this subject more thoroughly, learning that the formation of national ideologies is a more complicated process than the theories I had brought from home assumed. This research produced National Ideology under Socialism, dedicated to professor Prodan, who had inspired it. 
For my next book, The Vanishing Hectare, the conditions were completely different. In the summer of 1991, after the fall of Ceauşescu, I went to Vlaicu to see how people were doing. Everybody wanted to talk to me, to tell me their story about land restitution. I had not been particularly interested in the subject of property until then, but I remembered the word of one of my colleagues: research goes better when the topic is of interest for the researched population too. So I started to read about decollectivisation and returned to Vlaicu to investigate it.

This time, the research did not have a principal "godfather," like the rest. My initial dialogue partner was beloved professor Ioan Aluaş from Cluj, whom I had met in 1980. Until his sudden death that winter, he helped me very much indeed, and I dedicated to him an article entitled "The Elasticity of Land," which encapsulated the results of my investigations. But more than ever before, this time I owed the progress of my work to the help of many Vlăiceni, not to one or another professor. For example, Dorina and Lucreția, the two heads of the agricultural association; Florin and Ana, and other state farm directors; and, above all, the villagers who were claiming their lands and were eager to tell me about their victories and their disappointments. I mention Mărioara lu' Pompi (the daughter of Auntie Lina), Iosif Bota (the nephew of Uncle Petru), Ion Caraşca a lu' Niţu, and Maria lu' Relu, in particular, with whom I spent countless hours discussing how they coped with the demands of their restored hectares. This was my most successful research because, finally, I had learnt to do ethnography and had ceased to believe that $I$ knew the right answer; people were eager to recount what they were going through; and, even though rumours that I was spying persisted (as in the past), the majority of Vlăiceni didn't care anymore.

I pass over the book about collectivisation (Peasants under Siege) because you have heard about it from my colleague and friend Gail Kligman, with whom I wrote it. I only mention that our colleagues in our research team had great influence on the result; from Transylvania, I mention Virgiliu Țârău, Julianna Bodó, Sándor Oláh, and Călin Goina.

My two most recent books, Secrets and Truths and My Life as a Spy, concern my Securitate file. I hesitate to thank the Securitate officers for the data they collected for me, or for the whole nightmare of reading the file and writing the books, which were extremely difficult experiences. Still, in the spirit of knowledge, I admit that the experience was fascinating and taught me very much. I give you two examples.

The first regards a close friend, whom I call "Mariana." We became friends in the 1980s, going even beyond her 1988 confession that she had given reports about me to the Securitate. Even though we hadn't discussed the details then, since she was ashamed, I returned to the subject in 2010 after I had read her 
reports from the file. We talked for two full days, relating how she had been recruited, how she had felt, her meetings with the officer, the sleepless nights, her denying the label of "informer" ("I didn't feel that I had done something important, interesting. I never felt like an 'informer,' and I find it hard to use this word about myself."). After several hours of discussions, she said to me, "You did me so much harm!"

I thought a lot about these last words, trying to understand how a person who had reported on me could consider herself the victim and not the perpetrator. I went through several phases: months when I rejected her completely; months when I realised that a person who considers herself a victim can still keep her social relations - so crucial in Romanian society - while a perpetrator risks losing them; other months when I wondered whether a peculiar feature of the language of the reports - the use of the third person rather than the first, for the actions of the informer ("the source met target KV, who invited her to dinner") - produced a split of the perpetrator part from the self, preserving the integrity of the person; months when I saw her as a victim of the regime; and, finally, the conclusion that had I understood better how the regime functioned, had I not considered myself so clever without understanding myriad things, maybe I wouldn't have participated unknowingly in creating the trap in which she felt compelled to inform on me.

My reactions to these meetings with Mariana convinced me of the truth of an idea expressed by the famous American anthropologist Margaret Mead, who wrote, "the surest and most perfect instrument of understanding is our own emotional response, provided that we can make a disciplined use of it." My experience with Mariana fully proved the value of this idea - especially for ethnographers; sociologists' methodology does not usually invite such affective involvement. Thus, I can understand Mariana when she tells me "You did me so much harm!" - even though at the same time I believe that an informer has to admit her own responsibility for the role she has taken on. I praise Mariana for her courage in our meeting and for her power of self-analysis, which prompted me to analyse myself as well, and to confront seriously the dilemma she had posed for me: Who is the victim, and who is the perpetrator?

My last example is not an homage but another example of Margaret Mead's idea, which takes us to unexpected forms of knowledge. In September 2014, I discovered a website containing phones and addresses from Romania. I had a hunch and searched for information on several of my Securitate officers, and I found two. When I came to Romania several months later, I looked for one of them. I had brought with me a bunch of chrysanthemums. When I pressed the intercom, a voice answered; I said "I've got flowers for you" and the door opened. What the hell! What do I do now? I didn't have a plan, just some general questions. 
I will not bore you with all the details, but this meeting gave me a profound shock. I saw myself smiling so much my face hurt; talking at breakneck speed, incapable of calming my emotions; saying all sorts of nonsense to please him (how I understood why they followed me, because I had driven my Mobra into a military base, etc.). After a while, the man sat down on a chair (he had remained standing after I sat) and entered the dialogue. We talked for at least an hour, the atmosphere welcoming and pleasant. When I got up to leave, he extended his hand saying, "Please come again. Maybe we'll go out somewhere."

This meeting shook me powerfully - in the first place, by showing me first-hand how "friendly" a securist could be, bearing important consequences for his relations with informers. Later I realized that, in a way, he had recruited me, seduced me, despite the great fear I had had for his organisation. Several nights I couldn't sleep at all, with his image in my head, having the ridiculous feeling that I had made a new friend. (When I approached him a year later, he rejected me.) I had a similar experience with the second securist I had found through the telephone website: friendly, nice, a recruitment/seduction. These two meetings showed me that, although I had the courage to approach them, I did not have the strength to confront them.

***

Moving towards a conclusion, my main idea concerns the relation between theory and empirical data and what I have learned about it here. What separates my first two books (on ethnicity, and on national identity) from the others (two about villagers' relations with the land, and two about the Securitate) is the weight of theory in relation to field data. The first book, Transylvanian Villagers, was based on anthropological theories about interethnic relations, alongside sociological theories about "World Systems" - a huge framework in which the villager from Aurel Vlaicu, where I had conducted my research, could become lost. More than half of the book came from research in libraries and archives, not from relations with living people. National Ideology under Socialism was similar: a lot of readings and fewer conversations, all organized by theories of Pierre Bourdieu and Michel Foucault.

But in the book about decollectivisation, The Vanishing Hectare, the words of Vlăiceni and others represented the overwhelming source of my analysis and presentation. Because of this I consider it my best book, and also because the theoretical part did not overwhelm the empirical material. With this book I truly became an ethnographer. One can see this even in my last book, My Life as a Spy, about my relations with the Securitate, which is full of people's words my friends from Vlaicu, Cluj, and Bucharest; excerpts from the documents in my file; conversations with some of my officers and informers, etc. 
For someone who started off with the most fashionable macro-sociological theories, the fact that I end up with kinship and clientelism (very old topics in Anthropology) is, to say the least, surprising. But here is where my life and research in Romania brought me: to the overwhelming importance of the social relations that construct not only people's lives - but also knowledge about it. This may seem a modest achievement, but it is of the essence, and it is something I learned here, from Romanians.

I have spoken about several of the Romanians with whom I had important relations across the years and who influenced the way I understand your society. Under this guise I spoke about the ethnographer's methodology - a methodology which implies an epistemology. There were, of course, many other people - in Cluj, for example, there were Aurel Răduţiu, Pompiliu Teodor, Mihai Gherman, Liviu Maior, and the Marga and Ursuţiu families. I wanted to emphasize two ideas. First, that while starting from macro-models and a certain intellectual arrogance, I learned that ethnography demands a continuous desire to listen to people's opinions, and at the same time to use myself - my reactions, my sentiments - as an instrument for knowing. These practices distinguish ethnography from other social sciences. Second, that if my research has produced several good books, I owe these achievements less to my talents than to my Romanian colleagues and friends - to you - who have tried to teach me how to do better ethnography. The great honour awarded today should not be conferred on me alone, but on our collaboration.

\section{REFERENCES}

Kligman, G., and Verdery, K. (2011). Peasants under Siege: The Collectivization of Romanian Agriculture, 1949-1962. Princeton: Princeton University Press.

Verdery, K. (1983). Transylvanian Villagers: Three Centuries of Political, Economic, and Ethnic Change. Berkeley and Los Angeles: University of California Press.

Verdery, K. (1991). National Ideology Under Socialism: Identity and Cultural Politics in Ceaussescu's Romania. Berkeley and Los Angeles: University of California Press.

Verdery, K. (1994). Compromis și rezistență. Cultura română sub Ceaușescu. București: Humanitas.

Verdery, K. (2003a). The Vanishing Hectare: Property and Value in Postsocialist Transylvania. Ithaca, NY: Cornell University Press.

Verdery, K. (2014). Secrets and Truths: Ethnography in the Archive of the Romanian Secret Police. The Natalie Zemon Davis Lectures for 2012. Budapest: Central European University Press.

Verdery, K. (2018). My Life as a Spy: Investigations in a Secret Police File. Durham, NC: Duke University Press. 